\title{
Typology of Management of Transhumant Sheep and Goat Farms in Greece: Proposals for the System Continuity
}

\author{
A. Siasiou, C. Karelakis, K. Galanopoulos, I. Mitsopoulos, and V. Lagka
}

\section{ABSTRACT}

Transhumant farming system is one of the earliest agricultural activities in Greece having an important role in the conservation of biodiversity, the preservation of rural tradition and cohesion of the rural population. The objective of this study was to construct a transhumant farm typology that could be used as a tool by the decision makers or farmers to improve the management of the farms. The required information was obtained from totally 551 Greek transhumant producers. A Principal Component Analysis gave five components related to the production cost of the farms, the intensity of management, the evolution of the extensive character of the system, the type of herds and the future of the system. Using multivariate techniques, a farm typology was established with four categories. The three categories, were characterized by lower production cost and intensification rate while preserved generally a more extensive character. Among them the first group defined as "evolution of the farming system" bred mainly sheep and producers were significantly more adaptive to some kind of innovations, the second group was constituted mainly by large goat herds while the third one by small sheep herds'. The fourth group, defined as the "intensive one" meaning high production cost, intensification rate and working hours per female as well as limitation of time spent grazing. Besides the definition of the character of the transhumance nowadays the results interestingly, highlighted the future of transhumant farms that tends to be doubtful for a number of farmers originated mainly by the last group.

Keywords: extensive farming system, grazing intensification.
Published Online: January 29, 2021

ISSN: $2684-1827$

DOI: $10.24018 /$ ejfood.2021.3.1.228

\section{A. Siasiou*}

Democritus University of Thrace, Greece.

(e-mail: annasiasiou@yahoo.gr)

C. Karelakis

Democritus University of Thrace, Greece.

(e-mail: chkarel@agro.duth.gr)

K. Galanopoulos

Democritus University of Thrace, Greece.

(e-mail: k.galanop@agro.duth.gr)

I. Mitsopoulos

Alexander Technological Educational Institute of Thessaloniki, Greece.

(e-mail: gmitsop@ap.teithe.gr)

V. Lagka

Alexander Technological Educational Institute of Thessaloniki, Greece.

(e-mail: lagka@ap.teithe.gr)

"Corresponding author

\section{INTRODUCTION}

Transhumance is a traditional extensive farming system, mainly of sheep and goat, that permits the complementary exploitation of highland and lowland rangelands. The system involves the seasonal migration of herds towards mountainous and semi-mountainous areas' where flocks remain for 4 to 6 months according to climate conditions and plant's productivity [1], [2] while return to lowlands on autumn or even early winter [3].

In Greece the movement to uplands for the majority of the transhumant herds takes place in the second half of May while the return to lowlands during October [3]. However, an important number of herders (located mainly on Central Greece) move their flocks earlier on the mountainous rangelands, i.e., the movement takes place in early spring (until $31^{\text {st }}$ of April) [3], [4], due to the readiness of the grasslands that is associated with the mild climate of the area and the dry summer of the plains [3], [5]. Through grazing transhumance can be seen as a conservation tool with positive effects on biodiversity and plants regeneration while contributes importantly to the genetic and biological diversity, to fire prevention or to the maintenance of natural soils [6]-[9]. Besides the deep ecological role of the system other aspects of the systems' multidimensional role are the preservation of cultural identity, social function, affording population fixing, and economic dynamism in rural areas as well as the higher quality of the products [10]-[12].

The superior taste and chemical composition of meat and dairy products produced by animals grazing is affected by the dietary of the transhumant sheep and goats. Wood et al. [13], mentioned the positive impingements of such products on human health naming ratio of mono and poly unsaturated fat, cardioprotective omega-3 fatty acids and antioxidants while Frelich et al. [14], Metera et al. [15] highlighted that the higher composition on macro and micro elements is not only due to dietary with particular sward types and plant species but also to the genotype of the grazing animals, naming local livestock breeds. Interesting is also the notification by Pardini et al. [16] about consumers that are keen to pay 15-20\% more to buy products produced in natural environments and with traditional methods, mark that recommend important economic opportunities for the producers.

Although transhumance of small ruminant is being present to a lot of European countries, nowadays the system is in decline as many older transhumant herders retired while few younger remained to take over [12]. Interesting is also that the number of transhumant sheep and goat farms in Greece has been importantly reduced $(30 \%)$ during the second half of the 20th century, resulting to the decline of grazing pressure to summer rangeland [3]. Several authors have also studied the character of the system in Greece that has been 
evolved in various ways: through the genetic improvement of the reared animal (mostly uncontrolled), the abandonment of the traditional routes through mountainous rangelands and mechanization of movement or farming of smaller herds [3], [4]. According to Landaua et al. [17], during the later decades pastoral activity has been reconfigured leading to the formation of "new production systems" or "new types of the system" ought to probably the replacement of traditional breeds with improved dairy and/or the limitation of grazing. The emergence of "new types" of pastoral activity, however, is driving eventually to loss of the environmental benefits of the system.

FAO defines farming system as a group of farms that have similar resources bases, enterprise patterns, household livelihoods and constraints and for which similar development strategies and interventions would be appropriate. The construction of a Farm System Typology (STP) according to Madry et al. [18], demands the establishment of the purpose of the typology and of the elements that integrate the system. These 'elements' are related with the organization of the system, technology performed, the farm structure and social relations of the system. Examples of data collection and conduction of farm typology are Tindano et al. [19]; Guilherme et al. [20]; Gelasakis et al. [21]; Murphy and Meredith [22]. Within this perspective purpose of this paper was to classify transhumant herds according to the performed management practices and producer's characteristics and construct a farm typology as a tool for producers or decision makers to improve management of the system. Therefore, the paper analyzes technical, economic and productive aspects of the system by means of multivariate analysis.

\section{MATERIALS AND Methods}

Primary data were collected through a quantitative survey (structured questionnaire) to a random sample of 551 transhumant sheep and goat farmers. The questions were selected to obtain a general description of farm characteristics and overall management practices and included information about:

a) flock size and structure,

b) equipment,

c) feeding management,

d) reproduction and breeding strategies,

e) labour force,

f) lactation and cost production.

Variables representing all the essential inputs combined with all others, representing social, operational, production and structural attributes of agriculture were used to provide a basis for identification of the farming type of system.

Data were obtained in 2014 through personal interviews that were conducted by trained enumerators. Each interview lasted for 60 minutes on average due to complexity of the questionnaire. A combination of multivariate techniques, namely Principal Components Analysis and Cluster Analysis, were employed to identify explanatory variables and to group farms in homogenous types.

Initially Principal Components Analysis (PCA) was used to estimate the relations between variables and to reduce the original variance though the recognition of the new variables (factors). Eventually, this allows for reducing the number of variables and preserving the maximum variability of the sample. The variables used involved aspects of the farm's management.

The variables used in PCA were eleven including:

1. 'Intensification' of management was defined as an ordinal variable ranging from 1-lower to 14 higher degree of intensification. Because of the extensive character of the system any practice that could lead to higher production has been taken into consideration. Specifically the measures of 'intensification' of management taken into consideration were the supplementary feeding and the coverage of the nutritional needs of the herds during winter ranging from 0 to 4 according to the coverage of nutritional needs translated as ME (Metabolized Energy), DCP (Digestible Crude Protein) and DM (Dry Matter), the health prevention scheme (ranging from 0 to 5 according to the number of vaccination against main diseases), the early or not of lambing/kidding (ranging from 0 to 2 later to premature whether takes place after December, until December and until October) and the admittance age of females in reproduction (ranging from 3 to 0 whether takes place between 9 to 12 months, 12 to 15 months, 15 to 18 months and more than 18 months).

2. Production cost per female (euros per female)

3. Herd size (total number of animals including females, males and replacement animals).

4. Lactation (average number of days including duration during winter and summer)

5. Distance between winter and summer domiciles measured on $\mathrm{km}$

6. Index of 'new practices' was defined as an ordinal variable ranging from 0 to 5 . The variable was measured through the use of milking machine (ranging from 0 to 1 ), the performance of estrus synchronization (ranging from 0 to 1 ), the genetic improvement of the reared animals (from 0 belonging to mountainous breeds, 1 cross breeders with improved dairy breeds and 2 improved dairy breeders) and the facilitation of movement using trucks (from 0 to 1 ), taking into consideration essentially the adaption of practices that abstains by the extensive character of the system.

7. Average grazing hours during summer (total number of grazing during persistence on mountainous and semi mountainous rangelands)

8. Possess of land for forage and crop production

9. Number of working hours per female,

10. Animal, expressed as percentages of sheep to the total population of the herd.

11. Status of the farm, defined as an ordinal variable ranging from 3 to 8 . The variable was measured by the succession of the transhumant farm (ranging from 1 being positive, 2 being doubtful and 3 being negative), whether the successor decided on his own to take over the farm (ranging from 1 , being a personal choice and 2 being obligatory) and the age of the leader of the farm (defined as 1 under 30,2 between 30-59 years and 3 over 60).

Subsequently, a Cluster analysis was performed using the $\log$ likelihood logarithm to classify the farms using the factors with eigenvalue greater than 1, emerged from PCA, while a post hoc test (LSD) was performed to identify differences between the Groups for each factor. Firstly, a hierarchical partitioning algorithm was employed to create 3-, 4-, and 5- 
clusters of transhumant sheep and goat farmers. After the initial implementation of hierarchical cluster analysis, the method used the k-means procedure with the option of identifying 3, 4 or 5 clusters, in relation to the sample size (551 transhumant sheep and goat farmers). The 4 cluster, solution was finally adopted given the ease of interpretation and the highest number of statistically significant factorial differences between the clusters.

\section{RESULTS}

\section{A. Relationships between Performed Management} Practices and farmer's Characteristics

Five factors explaining the $61.22 \%$ of original variance were obtained in the PCA (Table 1).

Factor 1 named "management factor" reflected the positive relationship between working hours per female and the intensification variable. The intensification of management defined as the increase of supplementary feed and more efficient coverage of nutritional requirements of the animals, earlier entrance in breeding etc. demanded more working hours per female. These two variables constitute aspects of more intensive management adapted to lead to greater performance of the animals and better economic results.

The second factor, the "cost production factor", identified a positive relationship between investments of producers meaning nutritional cost, fixed, variable cost and cost of labor, and possess of land for forage and crop production. The utilization and harvest of land is an investment that contributes to greater adequacy and self-efficiency as nutritional management is concerned and independence by the seasonal fluctuations of market prices or availability of resources.
TABLE 1: CONTRIBUTION OF THE VARIABLES TO THE MAIN FACTORS IN

\begin{tabular}{|c|c|c|c|c|c|}
\hline & $\begin{array}{c}\text { Factor } \\
1\end{array}$ & 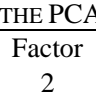 & $\begin{array}{c}\text { Factor } \\
3\end{array}$ & $\begin{array}{c}\text { Factor } \\
4\end{array}$ & $\begin{array}{c}\text { Factor } \\
5\end{array}$ \\
\hline Intensification & 0.838 & 0.204 & 0.023 & -0.043 & 0.010 \\
\hline Production Cost & 0.499 & 0.709 & 0.014 & -0.022 & 0.008 \\
\hline Herd size & -0.051 & 0.049 & 0.274 & 0.751 & -0.147 \\
\hline Lactation & 0.154 & 0.052 & 0.688 & -0.021 & 0.049 \\
\hline Distance & -0.081 & -0.087 & 0.476 & 0.226 & 0.128 \\
\hline $\begin{array}{c}\text { Index of } \\
\text { innovations }\end{array}$ & -0.087 & 0.077 & 0.633 & -0.144 & -0.062 \\
\hline Grazing hours & 0.231 & -0.347 & 0.362 & 0.127 & -0.445 \\
\hline $\begin{array}{l}\text { Possess of land } \\
\text { for forage and } \\
\text { crop production }\end{array}$ & 0.000 & 0.866 & 0.061 & 0.024 & -0.019 \\
\hline WU/female & 0.834 & -0.036 & -0.022 & 0.000 & -0.001 \\
\hline Animal & -0.015 & 0.041 & 0.273 & -0.783 & -0.087 \\
\hline $\begin{array}{l}\text { Status of the } \\
\text { farm }\end{array}$ & 0.075 & -0.066 & 0.159 & 0.003 & 0.892 \\
\hline
\end{tabular}

A Using Varimax Normalized Rotation. *KMO: 0.571 and p:0.000 of Bartlett's indicator.

Furthermore, the third factor identified the positive relationship between index of innovations, distance between winter and summer domiciles and lactation outlying that farms that traverse longer distances to reach uplands during summer adapted new practices such as mechanization of movement, genetic improvement or use of milking machine and had longer lactations, indicating a progressive change of management that does not alter the extensive character of the system and is characterized as "evolution of extensive system factor".

The fourth factor, the "type of herd" identified a negative relationship between herd size and the kind of the reared animal recognizing that sheep or mainly sheep herds are generally medium to small while goat herds are larger. The fifth factor, the "future factor" outlies the negative relationship between status of the farm and grazing hours. When the status of the farm become negative (higher) meaning no succession or lack of motives to occupy with extensive farming or elderly leaders, the hours the animals spent grazing are limited.

TABLE 2: AVERAGE CHARACTERISTICS OF THE GROUPS OBTAINED IN THE CluSTER ANALYSIS

\begin{tabular}{ccccc}
\hline & Group I & Group II & Group III & Group IV \\
\hline N & 65 & 196 & 180 & 110 \\
Variable & Mean \pm SD & Mean \pm SD & Mean \pm SD & Mean \pm SD \\
REGR factor score 1 & $0.01 \pm 0.73$ & $-0.036 \pm 0.73$ & $-0.37 \pm 0.54$ & $2.25 \pm 2.03$ \\
Intensification & $18.7 \pm 6.8^{\mathrm{c}}$ & $18.4 \pm 7.7^{\mathrm{c}}$ & $16.1 \pm 5.5^{\mathrm{a}, \mathrm{b}}$ & $40.1 \pm 23.4^{\mathrm{a}, \mathrm{b}, \mathrm{c}}$ \\
WU/female & $19.2 \pm 7.4^{\mathrm{c}, \mathrm{d}}$ & $18.3 \pm 7.7^{\mathrm{b}, \mathrm{d}}$ & $15.7 \pm 5.1^{\mathrm{a}, \mathrm{b}, \mathrm{d}}$ & $39.5 \pm 23.4^{\mathrm{a}, \mathrm{b}, \mathrm{c}}$ \\
REGR factor score 2 & $-0.25 \pm 0.62$ & $-0.09 \pm 0.64$ & $0.009 \pm 0.66$ & $1.84 \pm 0.45^{\mathrm{a}}$ \\
Production Cost & $152 \pm 78^{\mathrm{d}}$ & $159 \pm 92^{\mathrm{d}}$ & $155 \pm 82^{\mathrm{d}}$ & $462 \pm 221^{\mathrm{a}, \mathrm{b}, \mathrm{c}}$ \\
Possession of land for forage and & $8.6 \pm 12.8^{\mathrm{c}, \mathrm{d}}$ & $9.1 \pm 14.9^{\mathrm{c}}$ & $10.3 \pm 15.2^{\mathrm{d}}$ & $61.7 \pm 86.0^{\mathrm{a}, \mathrm{b}}$ \\
crop production (ha) & $0.86 \pm 0.56$ & $-0.22 \pm 0.52$ & $-0.67 \pm 0.62$ & $-0.031 \pm 0.81$ \\
REGR factor score 3 & $150 \pm 81^{\mathrm{b}, \mathrm{c}, \mathrm{d}}$ & $94 \pm 81^{\mathrm{a}, \mathrm{c}, \mathrm{d}}$ & $59 \pm 51^{\mathrm{a}, \mathrm{b}, \mathrm{d}}$ & $120 \pm 95^{\mathrm{a}, \mathrm{b}, \mathrm{c}}$ \\
Lactation & $208 \pm 40^{\mathrm{c}}$ & $204.9 \pm 55.2^{\mathrm{c}}$ & $177.3 \pm 49.7^{\mathrm{a}, \mathrm{b},}$ & $177 \pm 48$ \\
Distance & $3.3 \pm 0.9^{\mathrm{b}, \mathrm{c}, \mathrm{d}}$ & $2.3 \pm 0.8^{\mathrm{a}, \mathrm{c}}$ & $2.2 \pm 0.8^{\mathrm{a}, \mathrm{d}}$ & $2.5 \pm 0.9^{\mathrm{a}}$ \\
Index of innovations & $-0.40 \pm 0.58$ & $1.27 \pm 0.86$ & $-0.63 \pm 0.78$ & $-0.21 \pm 0.69$ \\
REGR factor score 4 & $5.34 \pm 1.08$ & $5.36 \pm 0.99$ & $5.40 \pm 0.97$ & $6.34 \pm 1.73^{\mathrm{a}}$ \\
Current status of the farm & $2.199 \pm 383^{\mathrm{b}, \mathrm{c}, \mathrm{d}}$ & $1923 \pm 374^{\mathrm{a}, \mathrm{c}}$ & $1732 \pm 316^{\mathrm{a}, \mathrm{b}, \mathrm{d}}$ & $1879 \pm 407^{\mathrm{a}}$ \\
Grazing hours & $-0.26 \pm 0.58$ & $0.04 \pm 0.86$ & $-0.12 \pm 0.78$ & $-0.54 \pm 0.69$ \\
REGR factor score 5 & $437 \pm 224^{\mathrm{b}, \mathrm{c}}$ & $699 \pm 351^{\mathrm{a}, \mathrm{c}, \mathrm{d}}$ & $277 \pm 158^{\mathrm{a}, \mathrm{b}, \mathrm{d}}$ & $393 \pm 256^{\mathrm{b}}$ \\
Herd size & $77 \pm 17^{\mathrm{b}, \mathrm{c}, \mathrm{d}}$ & $21 \pm 25^{\mathrm{a}, \mathrm{c}, \mathrm{d}}$ & $73 \pm 23^{\mathrm{a}, \mathrm{b}}$ & $68 \pm 28^{\mathrm{a}, \mathrm{b}}$ \\
\hline Animal & &
\end{tabular}

* Superscipts represent significant differences at $\mathrm{p}<0.005$ for the specific production objective when compared to another group based on post-hoc between groups. Group I:a, Group II:b, Group III: c and Group IV:d. 


\section{First group}

The first three groups are characterized by lower intensification $(\mathrm{p}=0.000)$ and cost production $(\mathrm{p}=0.000)$, lesser working hours per female $(\mathrm{p}=0.000)$, possession of land for crop and forage production to a lesser degree $(p=0.000)$ contrary to the fourth group while the "future factor" is quite low, indicating a promising future as the continuity of the system. Generally, these three groups seem to preserve a more traditional character that is however accompanied in some cases (mainly group I) by adaptions of kinds of innovations such as genetic improvement, or mechanization of movement. More specifically the first group I $(n=182)$ is constituted mainly by medium (average herd size of 440 animals) herds while sheep breeding $(\mathrm{p}<0.05)$ prevails $(78 \%)$. The group is also characterized by longest $(\mathrm{p}<005)$ lactations (150 days) as well as adaption of innovations. Analyzing the factor "index of innovations" in table 3 , is recognized that herds are genetically improved (mainly through crossbreeding) and producers have adapted movement by trucks in a higher degree contrary to the other two "extensive groups" ( $p=0.000$ for both parameters). Time spent grazing is significantly higher in this group $(\mathrm{p}=0.000)$ compared to the others (more than 2100 hours) while the distance between winter and summer domiciles is significantly longer than the $3^{\text {rd }}$ and $4^{\text {th }}$ group $(\mathrm{p}<0.05)$. Lastly the factor "future" is the quite low $(p<0.05)$ indicating a promising future for the system. This group can be named the "evolution of the traditional transhumant system".

TABLE 3. ANALYSIS OF THE VARIABLE "CURRENT STATUS OF THE FARM" AND "INDEX OF INNOVATIONS FACTOR" (\% PER VARIABLE)

\begin{tabular}{|c|c|c|c|c|c|}
\hline \multicolumn{2}{|c|}{ Factors } & $\begin{array}{c}\text { Group } \\
\text { I }\end{array}$ & $\begin{array}{c}\text { Group } \\
\text { II }\end{array}$ & $\begin{array}{l}\text { Group } \\
\text { III }\end{array}$ & $\begin{array}{l}\text { Group } \\
\text { IV }\end{array}$ \\
\hline \multicolumn{6}{|c|}{ Production cost } \\
\hline \multicolumn{2}{|c|}{ Fixed } & $52^{d}$ & $48^{\mathrm{d}}$ & $50^{d}$ & $225^{\mathrm{a}, \mathrm{b}, \mathrm{c}}$ \\
\hline \multicolumn{2}{|c|}{ Nutritional } & $65^{\mathrm{a}, \mathrm{d}}$ & $77^{\mathrm{a}, \mathrm{d}}$ & $70^{d}$ & $123^{\mathrm{a}, \mathrm{b}, \mathrm{c}}$ \\
\hline \multicolumn{2}{|c|}{ Land } & $8.6^{\mathrm{d}}$ & $9^{d}$ & $10^{\mathrm{d}}$ & $61^{\mathrm{a}, \mathrm{b}, \mathrm{c}}$ \\
\hline \multicolumn{2}{|c|}{ Rest } & $18^{\mathrm{d}}$ & $18^{\mathrm{d}}$ & $17^{\mathrm{d}}$ & $44^{\mathrm{a}, \mathrm{b}, \mathrm{c}}$ \\
\hline \multicolumn{6}{|c|}{ Current status of the farms (\%) } \\
\hline \multirow{4}{*}{$\begin{array}{l}\text { Age of the } \\
\text { farmer }\end{array}$} & $<30$ & 7.7 & 7.9 & 10.4 & 0 \\
\hline & $30-59$ & 79.7 & 84.6 & 75.8 & 87.5 \\
\hline & $>60$ & 12.6 & 7.5 & 13.8 & 12.5 \\
\hline & Yes & 32 & 33 & 31 & 31 \\
\hline \multirow[t]{2}{*}{ Succession } & Douptful & 38 & 47 & 43 & 34 \\
\hline & No & 30 & 20 & 26 & 35 \\
\hline \multirow[b]{2}{*}{ Motives } & Obligatory & 46.15 & 44.73 & 46.26 & 50 \\
\hline & $\begin{array}{l}\text { Concious } \\
\text { choise }\end{array}$ & 53.85 & 55.27 & 53.74 & 50 \\
\hline \multicolumn{6}{|c|}{ Index of innovations } \\
\hline \multirow{2}{*}{ Movement } & By feet & $\begin{array}{c}14.28 \\
b, c, b\end{array}$ & $49.34^{a}$ & $43.42^{\mathrm{a}}$ & $40.62^{a}$ \\
\hline & Mechanization & 85.72 & 50.66 & 56.58 & 59.38 \\
\hline \multirow{3}{*}{ Breed } & $\begin{array}{c}\text { Indigenous } \\
\text { Breeds }\end{array}$ & $23.07^{\mathrm{b}, \mathrm{c}}$ & $40.78^{\mathrm{a}, \mathrm{d}}$ & $45.85^{\mathrm{a}, \mathrm{d}}$ & $28.10^{\mathrm{b}, \mathrm{c}}$ \\
\hline & Cross breeders & 63.18 & 51.97 & 48.06 & 56.25 \\
\hline & $\begin{array}{c}\text { Improved } \\
\text { dairy breeds }\end{array}$ & 13.75 & 7.25 & 6.09 & 15.65 \\
\hline
\end{tabular}

\section{Second group}

The second group $(\mathrm{n}=152)$ is constituted mainly by large $(\mathrm{p}=0.000)$ goat $(\mathrm{p}=0.000$, more than $75 \%$ is constituted by goats)) herds, less genetically improved contrary to the $1^{\text {st }}$ and $4^{\text {th }}$ group (table 3 ), moved lesser by trucks contrary to rest groups and grazed on uplands rangelands approximately 1900 hours (table 2) pleading to the «more traditional and more extensive transhumant character» of this group.

Third group
The third group, "the remainder traditional peasant farming" $(\mathrm{n}=182)$ is characterized by small $(\mathrm{p}<0.05)$ (on average 270 animals) mainly sheep herds, that adapt innovations much lesser (animals less genetically improved) and graze approximately 1700 hours, significantly lesser than the other groups $(\mathrm{p}<0.05)$. Moreover, lactation is the least among the groups (60 days; $\mathrm{p}=0.000$ ) and the distance between winter and summer domiciles ranges to $170 \mathrm{~km}$ (lower than $1^{\text {st }}$ and $2^{\text {nd }}$ group; $\mathrm{p}=0.000$ ).

\section{IV.DISCUSSION}

\section{A. Relationships between Management Practices and Intensification}

PCA Factor 1 recognized a positive relationship between intensification of management and working hours a relationship confirmed by Cluster analysis where Group IV showed that when the intensification is high analogous high is the WU/female. Interesting is also that in Group IV herds graze less compared to the groups I and II (the more 'extensive') linked probably with the increase of indoor periods and indoor nutrition. In group IV also herds are characterized by increased cost production and to a higher degree possess of land for forage or crop production relationship depicted in factor 2 of PCA analysis.

Factor 3 indicates a positive relationship between lactation and distance between lowlands and uplands recognized in Group I where herds have long lactation (about 150 days) while distance traversed is more than $200 \mathrm{~km}$. More interesting however is that herds of group I adapted innovations (milking machine, mechanization of movement) significantly more than the other two groups $(\mathrm{p}=0.000)$. Also factor 5 naming the negative relationship between herd size and kind of the reared animals, is recognized in group II where significantly larger goat herds (less than $25 \%$ sheep of the populations) dominate and in group I where significantly small sheep (about $70 \%$ sheep) herds domain. Lastly factor 4 indicating a negative relationship between the status of the farms and the hours grazing to uplands, depicted in group I as the herds grazed more and the status of the farms was low indicating a favorable future meaning the age of the leader, the motives of being transhumant farmer and/or the existence of successor while in Group IV the adverse relationship is recorded, animals graze less while the "future of the system factor" indicates a doubtful future. In group III, the hours the herds spend grazing is quite low but is not accompanied with analogous high score on factor 4 as was expected. It should be mentioned that herds in group III "the peasant", that represent the remainder of so called "pendulation" and evolved in this manner meaning having smaller herds, of mainly sheep breeding and of lower lactations is not threatened.

In addition a Spearman's correlation was performed between the factors obtained by PCA analysis, revealing a negative relationship between factor 1 and 5. This finding indicates that when the "cost production" factor increases the "current status of the farm" factor decreases a relationship that defines that when investments in the system are higher the possibilities of the farm to continue to move the herds between winter and summer domiciles decline and/or the 
motives of occupation with transhumance are mostly obligatory. This relationship is reaffirmed in group II where the factor 1 is the least and the factor 5 the higher, implying that the future of the system is favorable or the motives of occupation is not obligatory for producers that invested lesser.

\section{B. Kind of Reared Animals and Continuity of the Farms}

Studying the grouping of the transhumant herds that emerged from Cluster analysis we ascertain that breeding of transhumant sheep and goats differs even among the «borders» of the same farming system. Particularly we noticed that goats' breeding has strong extensive character as Groups II (where the majority of goats belong) spent much time grazing (much longer than groups III and IV), the cost production and nutritional cost was quite low and the herders did not proceed in adaption of new practices (index of innovations) or of more intensive management practices (according to management intensification) estrus synchronization etc. revealing the preservation of the traditional profile of the system.

On the other hand, the breeding of transhumant sheep is distinguished in three different ways. The first one 'the extensive' is characterized by the herds of group I and III where sheep form medium to large herds, production cost is relatively small, while nutritional management, taking into consideration the nutritional cost, is based on grazing. On group III 'the peasant one' sheep constitute small herds; production cost remains low, animals graze less; while lactation is the least is the sample. Lastly according to the third one, 'the intensive' represented by Group IV, herds' production cost and intensification score is relatively high. Moreover, producers adapt more intensive practices and are open minded in application of some kind of innovations.

Looking into the "future of the system" factor, the general picture is deterring as only the $33 \%$ will surely continue to exist in the next, of the current herder's, generation. The majority of these herders belong to groups II and III, results that reaffirm previous literature by Riedel et al. [23]; Mena et al. [9]; Ruiz et al. [1] and Caballero et al. [10].

\section{CONCLUSION}

The lack of assurance of farms continuity, limitation of grazing, crossbreeding and mechanization of movement are resulting in many ways to loss of natural conservation and abandonment of a farming system with beyond environmental great social economic and traditional role. During the last 50 years many older animal keepers have retired while very few younger remained to take over [3]. Generally, new farmers tend to adapt more intensive practices and a way of life more comfortable instead of the nonconvenient conditions that transhumant herders come up with. Transhumant herders often face difficulties to increase or even preserve their income while during their persistence on uplands they come up with the long distances to markets and the harsh conditions of not always friendly environment and the continuous challenge to be competitive contrary to the intensive farmers. However, employment in a family exploitation, during the general economic crisis, could be an option ought to lack of opportunities. The challenge is the new producers, the successors, not to abandon this farming practice and not been oriented to more intensive animal production systems.

To keep this system from disappearance technical, political and farmers must assume the challenge of making the farms sustainable. The association of transhumant farmers and labeling of products could prove efficient and improve the price of grazing meat and milk as a label provides consumers an identity that value. The prompting of aggregation in a territory of transhumant herders so as to build local chain of supplementation of by-products could prove also efficient.

Another measure could be the training of herders to implementation of management strategies in order to maximize the use of natural resources. The implementation of integrated breeding programs of indigenous sheep and goat breeds could lead to avoidance of cross-breeding. This practice could reverse the loss of biodiversity of Greek indigenous mountainous breeds that took place the last decades in animal production in Greece.

Furthermore, taking advantage of "mountain products" which was introduced by the EU regulation 1151/2012, as transhumant products fulfil the requirements that demand both raw materials and farm animal feedstuffs come primarily from mountain areas and the transformation of the food product being carried out in a mountain area, could be an economic opportunity for the transhumant herders. From the above emerges the need for protection of the tradition food practices and recipes that need to be handed down to the new generations.

Moreover, as compensation strategies is concerned even though transhumance and pastoral activities are not directly mentioned in the CAP reform of 2014-2020, is covered under Pillar 2 that includes agri-environmental schemes as Less Favoured Areas (LFAs) payments (as much of the land used in the system is LFAs, including mountainous grasslands and Agri-Environmental Measures (AEMs) (if producers implement practices environmentally friendly). According to Beaufoy et al [24] and Liechti and Biber [12] the majority of the EU policy support are absorbed by intensive agriculture systems and less by low intensity livestock keepers. From the above arises the need for implementation of integrated strategies that would aim environmentally friendly practices as transhumance and/ or mobile pastoralism.

Within this perspective the challenge for the future of transhumance is to ensure continuity by increasing public awareness for the multifunctional role of the system naming environmental, economic, social and cultural benefits and mostly communicate that the cost of losing the system is much higher that the effort is needed to preserve it.

\section{ACKNOWLEDGMENT}

This paper is part of the project "The dynamics of the transhumant sheep and goat farming system in Greece. Influence on biodiversity" which is co-funded by the European Union. 


\section{REFERENCES}

[1] M. Ruiz and J.P Ruiz, "Ecological history of transhumance in Spain." Biological Conservation, Vol 37, pp 73-86, 1986 , https://doi.org/10.1016/0006-3207(86)90035-2.

[2] A. Koocheri, and S.R. Gliessman, Pastoral nomadism, a sustainable system for grazing land management in Arid Areas. J. Sustain. Agric. vol 25, pp113-131, 2008, https://doi.org/10.1300/J064v25n04_09

[3] A.Siasiou, K. Galanopoulos, I. Mitsopoulos, A. Ragkos, and V. Lagka, Transhumant sheep and goat farming sector in Greece. Iranian Journal of Agricultural Science, 2018, http://ijas.iaurasht.ac.ir/article_544723.html.

[4] I. Mitsopoulos, A. Siasiou, D. Chatziplis, S. Kiritsi, V. Michas, V. Lagka and K. Galanopoulos, "Transhumant sheep and goat farming sector in Sterea Ellada-Greece" Animal Science and Biotechnologies,48:157-160, 2015, International Association of Agricultural Economists (IAAE) Conference, August 9-14, 2015, Milan, Italy.

[5] R. Baumont, S. Prache, M. Meuret, and P. Morand-Fehr, "How forage characteristics influence behavior and intake in small ruminants: a review". Livestock Production Science64: 15-28, 2000, https://doi.org/10.1016/S0301-6226(00)00172-X.

[6] G. Zervas, Quantifying an optimizing grazing regimes in Greek mountain systems. Journal of Applied Ecology,35:983-986, 1998, https://www.researchgate.net/publication/228019980.

[7] C. Köbrich, T. Rehman, M. Khan, "Typification of farming systems for constructing representative farm models: two illustrations of the application of multivariate analyses in Chile and Pakistan" Agr Syst 76, 141-157, 2003, https://doi.org/10.1016/S0308-521X(02)00013-6.

[8] F.P, Morand, Recent developments in goat nutrition and application: A review. Small ruminant research, 60: 25-43, 2005, https://doi.org/10.1016/j.smallrumres.2005.06.004.

[9] Y. Mena, J.M. Castel, R. Jimenez and F.A Ruiz, "Sustainability analysis of small ruminant farms involved in the conservation of natural resources". Options Mediterraneenees. 100, 119-124, 2001, http://om.cih eam.org/article.ph p?ID PD F=801 492.

[10] R. Caballero, "Typology of cereal sheep farming systems in Castile La Mancha South Central Spain.” Agri. Syst. 68, 215-232. 2001, https://doi.org/10.1016/S0308-521X(01)00009-9.

[11] I. Hadjigeorgiou, "Past, present and future of pastoralism in Greece". Pastoralism: Research, Policy and Practice,1:24, 2011, https://pastoralismjournal.springeropen.com/articles/10.1186/20417136-124.

[12] K. Liechti and J.P Biber, "Pastoralism in Europe: characteristics and challenges of highland- lowland transhumance.", Revue Scientifique et Technique (International Office of Epizzotics)"35 (2): 561-575,2016, http://dx.doi.org/10.20506/rst.35.2.2541

[13] J.D. Wood, R.I. Richardson, G.R. Nute, A.V. Fisher, M.M. Campoo, E. Kasapidou, P.R Sheard and M. Enser, "Effects of fatty acids on meat quality: A review", Meat science 66 (1): 21-32, 2004, DOI: 10.1016/S0309-1740(03)00022-6.

[14] J. Frelich, M. Slachta, O. Hanus, J. Spinka and E. Samkova, "Fatty acid composition of cow milk fat produced on low-input mountain farms", Czech Journal of Animal Science 54 (12), 531-539, 2009, DOI: $10.17221 / 226 / 2009-C J A S$.

[15] E. Metera and T. Sakowski, "Grazing as a tool to maintain biodiversity of grasslands". Anim. Sci. Pap. Rep. 28, 315-334, 2010.

[16] A. Pardini and M. Nori, "Afro-silvo-pastoral systems in Italy: integration and diversification", Pastoralism: Res. Pol. Pract. 1, 1-26, 2011, https://doi.org/10.1186/2041-7136-1-26.

[17] S. Landaua, A. Perevolotsky, D. Bonfilb, D. Barkai and S. Silanikove, "Utilization of low-quality resources by small ruminants in Mediterranean agro-pastoral systems: the case of browse and aftermath cereal stubble". Livestock Production Science 64: 39-49, 2000 https://www.sciencedirect.com/science/article/abs/pii/S03016226000, 174.

[18] W. Madry, Y Mena, B. Roszkowska-Madra, D. Gozdowski, R. Hryniewski. and J.M. Castel, "An overview of farming system typology methodologies and its use in the study of pasture-based farming system: a review". Spanish Journal of Agricultural Research 11(2), 316-326, 2013, 10.5424/sjar/2013112-3295.

[19] K. Tindano, N. Moula, A. Traoré, P. Leroy and N. Antoine- Moussiaux, "Characteristics and typology of sheep herding systems in the suburban area of Ouagadougou (Burkina Faso)", Arch. Anim. Breed, 58, 415423, 2015, DOI: 10.5194/aab-58-415-2015.

[20] R.F. Guilherme, A.M.C. Lima, D.F. Costa, R.R Pinheiro, F.S.F. Alves, S.S Azevedo, C.J. Alves, "Characterization and typology of sheep and goat production systems in the State of Paraíba, a semi-arid region of northeastern Brazil". SEMINA: CIENCIAS AGRARIAS vol 38 (4), pp. 21-63, 2017, http://dx.doi.org/10.5433/1679-0359.2017v38n4p2163.
[21] A.I. Gelasakis, G.E. Valergakis, G. Arsenos and G. Banos, "Description and typology of intensive Chios dairy sheep farms in

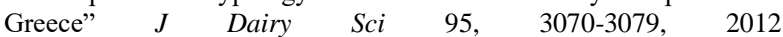
https://doi.org/10.3168/jds.2011-4975.

[22] G. Murphy and D. Meredith, A typology of cattle farmers in Ireland An overview of data, method and indicators. International Association of Agricultural Economists (IAAE) Conference, August 9-14, 2015, Milan, Italy.

[23] J.L. Riedel, I. Casasus, A. Bernués, "Sheep farming intensification and utilization of natural recourses in a Mediterranean pastoral agroecosystem", Livestock Science,111:153-163, 2007 , https://doi.org/10.1016/j.livsci.2006.12.013.

[24] G. Beaufoy, C. Keenleyside and R. Oppermann "How should the EU and national policies support HNV farming? In High Nature Value farming in Europe", (R. Oppermann, G. Beaufoy \& G. Jones, eds) Verlag Regionalkultur, Basel, 525-535, 2012 , https://www.researchgate.net/publication/313649423_How_should_E U_and_national_policies_support_HNV_farming. 